\title{
Economic Consequences of Implementing the Engagement Partner: Signature Requirement in the UK
}

\author{
Min Liu ${ }^{1}$ \\ ${ }^{1}$ Department of Accounting, Brooklyn College, Brooklyn, NY 11210, United States \\ Correspondence: Min Liu, Department of Accounting, Brooklyn College, Brooklyn, NY 11210, United States
}

Received: June 19, 2017

Accepted: July 27, $2017 \quad$ Online Published: August 16, 2017

doi:10.5539/ibr.v10n9p141

URL: https://doi.org/10.5539/ibr.v10n9p141

\begin{abstract}
This paper examines whether and the extent to which requiring the audit engagement partner (EP) signature influences on information asymmetry, analysts' forecast errors, and forecast dispersion. I predict and find that, ceteris paribus, there is a significant decline in information asymmetry, analysts' forecast errors and forecast dispersion from the pre- to post-EP signature period in the UK over both of short-term (i.e., 2008-2010) and long-term (i.e., 2004-2014). These findings hold when using a control sample approach, indicating that my results are not likely due to the effect of concurrent events and correlated omitted variables. These findings suggest that implementing the EP signature requirement benefits analysts forecasts over a short- and long-term.
\end{abstract}

Keywords: engagement partner signature, audit quality, information asymmetry, analysts' forecast errors and forecast revisions

\section{Introduction}

This paper investigates economic consequences of requiring the audit engagement partner (EP) to sign the audit report in the United Kingdom (UK) over a short- and long-term. This topic is important. Although Carcello and Li (2013) document that there is an increase in audit quality in the post-signature period, comparing to the pre-signature period. One function of an audit is to increase credibility of the financial statements. However, there is a lack of evidence on whether and how the EP signature requirement influences financial statement users, who may ultimately benefit from the improved quality of financial statements. Analysts are a group of financial statement users. I therefore investigate the effect of requiring an EP to sign audit reports in the United Kingdom (UK) on analysts' information environment to evaluate whether the regulation benefits the financial statement users, from the standing point of analysts.

Specifically, I examine two research questions. I first investigate how the EP signature requirement impacts the information asymmetry, analysts' forecast errors, and analysts' forecast dispersion. Theoretical disclosure literature argues that more publically available information and more precise information reduces information asymmetry, thereby improving information environment (e.g., Diamond and Verrecchia 1991; Lang and Lundholm 1993 and 1996; Easley and O'Hara 2004; Lambert, Leuz, and Verrecchia 2007). ${ }^{1}$ There was an information asymmetry problem between managers and investors in the pre-EP signature period because the EP's name was only available to managers but not to the public. Consistent with theoretical prediction, I expect that disclosing the EP's name reduces this information asymmetry in the post-EP signature period.

Further, accountability theory suggests that, in the post-EP signature period, an EP's accountability increases because of disclosure of his/her name, which should make the EP devote more effort to the engaged audit, thereby increasing audit quality (PCAOB 2011; Carcello and Li 2013; Cole 2014; Carcello and Santore 2015). The higher audit quality increases the credibility of financial statements. Therefore, financial statement users (e.g., analysts) should have more reliable information to predict future earnings. Therefore, I expect that analysts forecast errors and dispersion should decrease in the post-signature period compared to pre-signature period.

\footnotetext{
${ }^{1}$ Lambert, Leuz, and Verrecchia (2011) further analytically show that with imperfect market competition, information affects cost of equity capital even after controlling for the average investor's average precision. I control for the market competition in my analyses on the effects of requiring EP signature on cost of equity capital.
} 
To test my hypotheses on the economic outcomes of implementing EP signature requirement, I form a sample of UK firms having all required data in both last year in the pre-EP signature period and the first year in the post-EP signature period (e.g., a balanced panel design). I measure information asymmetry among analysts following Barron, Kim, Lim, and Stevens (1998) and analysts' forecast errors and analysts' forecast dispersion following Byard, $\mathrm{Li}$, and $\mathrm{Yu}$ (2011). I use an indicator variable, POST, to capture the impact of the implementation of the EP signature requirement on the economic consequences. Then, I regress these outcome variables on POST and other factors that may influence these economic consequences. I find a significant decrease in analysts' forecast errors and forecast dispersion for the UK firms in the post-EP signature period compared with pre-EP signature period over the short term period (i.e., 2008-2010) when using the balanced panel design. I then extend the tests to a longer sample period of 2004-2014 and repeat my analyses because it is important to know whether the effect of EP signature requirement on the analysts information environment holds in long run. I find that the UK firms experience a significant decrease in information asymmetry, as well as a signific ant decline in analysts' forecast errors and dispersion in the post-EP signature period compared pre-EP signature period over the long term period (i.e., 2004-2014)

Further, to mitigate the confounding effects that may lead to the association between economic outcome variables and the EP signature requirement in the UK, I use a difference-in-difference approach similar to Daske et al. (2008); Carcello and Li (2013) and Byard et al. (2011). I compare the changes in these economic outcome variables for firms in the UK from the pre- to post-signature period with the changes in these variables for firms in the U.S. during the same period. The U.S. had not adopted the EP signature requirement yet by the end of the fiscal year 2014. Therefore, firms in the U.S. comprise the control sample not subject to change, unlike the treatment sample firms in the UK. When I compare the UK firms with the U.S. firms, I find that the UK firms experience a significantly greater decrease in the information asymmetry, as well as a reduction in the analysts' forecast errors and dispersion over the long term period.

Overall, the findings make a number of contributions. First, the collective results provide informative inferences to the U.S. regulators who are calling for empirical evidence on whether the proposed mandatory disclosure of the EP's name "provide[s] investors and other financial statement users with useful information" and on the cost-benefit analysis of the mandatory disclosure of the EP name (PCAOB 2013). The effects of the EP signature requirement on analysts' information environment would in part lend credit to the PCAOB's belief that the disclosure of the identity of the EP in the auditor's report benefits financial statement users. The result of less information asymmetry from the pre-signature period to post-signature period supports the PCAOB's claim that the mandatory disclosure of the EP's identity will increase the transparency of the audit process and decrease information asymmetry, thereby promoting investors' activism, including better prediction of the firm's performance.

Moreover, the results of more accurate analysts' forecasts and less dispersion in the post-signature period also lend credit to the PCAOB's $(2011,2013$, and 2015) argument that disclosing the EP's identity should increase the EP's accountability. When the EP is more accountable, the EP's clients are more likely to have higher quality financial statements, consequently benefiting financial statements users.

Furthermore, this paper builds upon previous literature by showing the extent to which an auditing regulation affects analysts' information environment. Further, this paper tests the theory related to disclosure and accountability in a unique setting, in which there was a change in the level of information asymmetry and a change in accountability of the EP from the pre- to post-signature requirement period. This change in the information asymmetry provides an ideal environment to test the debate on whether disclosing EP's name is useful to the information users and the debate on whether increased accountability of EP benefits the markets.

This paper proceeds as follows. Secion 2 reviews relevant literature and Section 3 develops my hypotheses. Section 4 details my research method. Section 5 describes sample selection and sample statistics. Section 6 reports results and Section 7 concludes my findings.

\section{Literature Review and Hypotheses Development}

\subsection{Literature Review}

A few European countries (e.g., France, Germany, and Luxembourg) required the EP to sign the audit report (US Department of Treasury 2008) before 2006. The European Union (EU) implemented the EP signature requirement through adopting Eighth Company Law Directive (Directive 2006/43/EC) in 2006. Soon after, the UK mandated the EP's signature in and after April 2009 (PwC Legal 2010). ${ }^{2}$ China and Taiwan also required the

${ }^{2}$ The term statutory auditor is equivalent to the term engagement partner as defined in the International Standards 
EP to sign his/her signature. The U.S., from 2008 to 2015, had proposed to pass (PCAOB 2011, 2013), and, in 2015, passed (PCAOB 2015) the similar requirement of asking the EP to disclose her/his name in the audit report.

Since the disclosing the EP's name in the EU countries has been a relatively recent development, empirical studies on the consequences of this disclosure are limited. ${ }^{3}$ Studies use the EP identification to document that individual engagement partners' tenure and rotation are related to perceived audit quality (e.g., Azizkhani, Monroe, and Shailer 2013; Lennox, Wu, and Zhang 2014). The researchers suggest that mandatory rotation of engagement partner leads to higher quality audits in the years immediately surrounding rotation. Moreover, Knechel et al. (2015) and Aobdia, Lin, and Petacchi (2015) also provide evidence that the EPs are influential to their clients.

Likewise, using a larger sample from the UK, Carcello and $\mathrm{Li}$ (2013) hypothesize and find that requiring the EP signature will increase the EP's accountability, thereby improving audit quality. John, Liu, and Sunder (2017) investigate and find that the implementation of the EP signature requirement is associated with an improvement in the disclosure quality, a decrease in the costs of capital, and an increase in the values of the client firms. John et al.'s findings suggest that implementing the EP signature requirement not only can improve audit quality, but also can economically benefit client firms.

Finally, Liu (2017) examines how the adoption of engagement partner signature requirement impacts analysts' information environment, using the UK firms as the test sample and the French, German, and Netherlandic firms as the control sample. Employing difference-in-difference analyses, Liu (2017) finds there was an increase in the analysts' following and analysts' forecast accuracy as well as a decrease in the analysts' forecast dispersion from the two-year-pre to the two-year-post-signature period. While this paper extends her study by testing the long-term effect of the EP signature requirement on the analysts' information environment, this paper is different from Liu (2017) in terms of using different proxies for analysts' information environment and over different longer test periods. Although Liu (2017) finds that the implementation of EP signature improves analysts information environment over 2-year period, we do not know if the effect of the EP signature on analysts information environment holds over long-term period, which also is the goal of this regulation.

\subsection{Hypotheses Development}

Accountability is defined as the quality or state of being accountable: an obligation or willingness to accept responsibility or to account for one's actions (Merriam-Webster 2003). The theory of judgement and decision making argues that people are often accountable for their judgement and decisions (Tetlock 1985; Beach and Mitchell 1978). Accountability strongly impacts the decision marker's information process and judgement no matter it is self-imposed or not (e.g., supervisor, organizational rules, or regulations). The demand of accountability arises from the need of exerting more cognitive effort to think carefully about the alternatives or to use thorough analytic skills (McAllister, Mitchell, and Beach 1979; Chaiken 1980; Hagafors and Brehmer 1983; Tetlock, Skitka, and Boettger 1989). Auditor is accountable for his/her audit. Accounting research documents that accountability makes the auditor put more effort to the engaged audit, thereby, resulting in a higher audit quality in different settings. For example, accountability is positively associated with judgement consistency and consensus (e.g., Johnson and Kaplan 1991; DeZoort et al. 2006) and judgement accurancy for bond quality (e.g., Ashton 1992). Accountability also could reduce cognitive bias (e.g., Kennedy 1993). Carcello and $\mathrm{Li}$ (2013) hypothesize that requiring an EP's signature would increase the EP's accountability, thereby, improving audit quality in the UK. Their results are consistent with an improved audit in the post-EP signature in the UK.

According to Directive 2006/43/EC (Article 2 (6)), the engagement partner who has the leadership role in an audit is responsible for the engagement and its performance. As a result, the EP is accountable for the appropriate supervision of the work of the engagement team members and for compliance with International Standards on Auditing that regard using the work of specialists, other auditors, internal auditors, and others who are involved in testing controls.

Furthermore, identifying EP's name is essential to hold the EP to be personally accountable. In the pre-signature period, the EP's identity was only known by limited people (e.g., managers and regulators). In the post-signature

on Auditing (PwC Legal 2010).

${ }^{3}$ EP's identity is disclosed when EP signs his/her name. Therefore, I interchange the term EP signature requirement and disclosing EP's name. 
period, the EP's name is disclosed to public, which would provide additional motivation for the EP to avoid any possible association with audit failure (DeZoort et al. 2006). The association with the audit failure may cause devaluing the EP's reputation and/or embarrassing the EP's family, friends, neighbors, and the press (Carcello and Li 2013). Such negative consequences may motivate the EP to work more diligently. Therefore, disclosing the EP's name (or requiring the EP's signature) should improve the overall audit quality in the post-signature period. The higher audit quality is associated with higher financial statement quality; these benefits were confirmed in Carcello and $\mathrm{Li}$ (2013). Higher quality financial statements are regarded as a higher quality disclosure. Lower information asymmetry in the market and less uncertainty among financial statement users is therefore expected (Lang and Lundholm 1993, 1996).

Second, theoretical literature generally assumes that information asymmetry arises between informed and uninformed investors (e.g., Glosten and Milgrom 1985; Kalay 2012). Informed investors have access to the private information about the firm while uninformed investors do not, which creates an information asymmetry problem. Releasing public information has two common benefits (e.g., Diamond 1985). First, it reduces costs of obtaining such information if the public information was not released. Second, it improves risk sharing because the public disclosure makes investors' beliefs more homogeneous and decreases speculative trades. In sum, econo mic theory generally indicates that increased disclosure reduces information asymmetry between the firm and market participants or between informed and uninformed investors (e.g., Beyer et al. 2010). Empirical results also generally support this negative association between the level of disclosure and information asymmetry (e.g., Amihud and Mendelson 1986; Welker 1995; Healey et al. 1999; Leuz and Verrecchia 2000). Combined, I expect that information asymmetry declines after implementing the EP signature requirement. Thus, my first hypothesis in alternative form is as follows. ${ }^{4}$

H1: The implementation of the EP signature requirement is associated with decreased information asymmetry.

Empirical studies also support the theoretical prediction that a high quality disclosure is associated with decreased forecast errors and forecast dispersion (Lang and Lundholm 1996; Ashbaugh and Pincus 2001; Ernsberger et al. 2008; Hodgdon et al. 2008; Bae et al. 2008; Byard et al. 2011; Barth et al. 2012; Horton et al. 2013). Financial statements users have more information about the audit process and the EP's quality in the post-EP signature period than pre-EP signature period. Moreover, the EPs are more accountable in the post-EP signature period than pre-EP signature period, which should lead to a higher quality audit. A higher quality audit usually is associated with more credible financial statements. Analysts should have better judgement about the firm's future performance when they use more reliable financial statements in their forecasts. Therefore, I expect that analysts should make smaller forecast errors in the post-EP signature period than pre-EP signature period. Thus, my second hypothesis is stated below.

H2: The implementation of the EP signature requirement is associated with decreased forecast errors.

In the post-EP signature period, analysts have more publically available information about the EPs whom the firms hire. Analysts can evaluate the EPs' performance using more publically available data in the post-EP signature period than pre-EP signature period. As a result, the forecast discrepancies among analysts may reduce in the post-EP signature compared to pre-EP signature period. Therefore, my third hypothesis is stated below.

H3: The implementation of the EP signature requirement is associated with decreased forecast dispersion.

\section{Research Design}

I adapt the Byard et al. (2011) model to test my first, second, and third hypotheses about the effects of the EP signature requirement on the information asymmetry, analysts' forecast errors and dispersion by adding an indicator variable, POST, capturing the effect of implementation of EP signature requirement. ${ }^{5}$ My first, second, and third hypotheses predict that information asymmetry, analysts' forecast errors and dispersion reduced in the post-EP signature period compared with the pre-EP signature period. I use the equation (1) to determine the effect of the EP signature on the information asymmetry, analysts' forecast errors and dispersion in the UK (firm $i$ and time $t$ subscripts are omitted for brevity): ${ }^{67}$

\footnotetext{
${ }^{4}$ All hypotheses are stated in the alternative form.

${ }^{5}$ Lehavy, Li, and Merkley (2011) and Horton, Serafeim, and Serafeim (2013) also use similar models to test the effects of annual report readability and IFRS, respectively, on the analysts' information environment.

${ }^{6}$ Since information asymmetry, analysts' forecast errors and dispersion may be impacted by analysts' coverage and analysts' coverage may be influenced by information asymmetry, analysts' forecast errors and dispersion (e.g., endogeneity issue), I also use a fitted value of AnCov in the regression in my sensitive analyses.
} 


$$
\begin{gathered}
I S, F E, \text { or Dispersion }= \\
\beta_{0}+\beta_{1} \text { POST }+\beta_{2} \text { AnCov }+\beta_{3} \text { Size }+\beta_{4} R O A+\beta_{5} M B+\beta_{6} \text { Horizon }+\beta_{7} \text { Leverage }+\beta_{8} \text { Intangible }+ \\
\beta_{9} B i g 4+\beta_{10} A B A Q+\varepsilon
\end{gathered}
$$

In the information asymmetry (IS), analysts' forecast errors $(F E)$, and analysts' forecast dispersion (Dispersion) regressions, I control for analysts following ( $A n C o v)$, firm size (Size), profitability (ROA), growth opportunities $(M B)$, forecast horizon (Horizon), leverage (Leverage), intangible assets (Intangible), the Big Four auditor (Big4), and accounting information quality $(A B A Q)$. Prior research has shown that these variables impact analysts' forecasts in at least some circumstances (Bhushan 1989; O'Brien and Bhushan 1990; Lang and Lundholm 1996; Barth, Kasznik, and McNichols 2001; Byard et al. 2011; Tan et al. 2011).

The firms with more analyst following may have more diversified forecast opinions, subsequently less consensus among analysts. I therefore expect the estimated coefficient on AnCov to be positive (e.g., Horton et al. 2013). The larger firms and firms with more analysts following tend to have smaller forecast errors and dispersion, while information asymmetry (IS), analysts' forecast errors $(F E)$, and analysts' forecast dispersion (Dispersion) increase along with increasing forecast horizon (Horizon). I do not predict the signs of the estimated coefficients of $R O A, M B$, and Leverage because of the unclear relationship between $I S, F E$ and Dispersion and these three variables. The firms having large amount of intangible assets tend to have more information asymmetry issues; therefore, analysts tend to have larger forecast errors and more forecast dispersion for these firms. Thus, I expect the estimated coefficient on Intangible to be positive in information asymmetry (IS), analysts' forecast errors $(F E)$ and dispersion (Dispersion) regressions. Previous research suggests that firms audited by Big4 auditors tend to have less information asymmetry problem, smaller analysts' forec ast errors and dispersion. Therefore, I expect the coefficients on Big4 to be negative in the information asymmetry (IS), analysts' forecast errors ( FE) and dispersion (Dispersion) regressions (e.g., Byard et al. 2011). Following literature, I expect a positive relationship between $I S, F E$ and Dispersion and $A B A Q$ (e.g., Lobo, Song, and Stanford 2012).

The POST variable captures the effect of the EP signature on the analysts' information environment. If the EP signature requirement improves analysts' information environment in the post-signature period, the coefficient on POST, $\beta_{1}$ is expected to be negative in equation (1).

\section{Sample Selection and Descriptive Statistics}

\subsection{Samples}

I collect analysts' forecast data for international firms from the $\mathrm{I} / \mathrm{B} / \mathrm{E} / \mathrm{S}$ international detail file, and financial and security data from Global Vantage $(\mathrm{GV}) .^{8}$

To test my hypotheses 1,2, and 3, I select all UK firms with required financial data. I then exclude firms in the banking (SIC 6000-6999) and utility (SIC 4813, 4900-4999) industries because they are under different regulations and have different financial structures from other industries. After deleting observations with missing financial statement data from Compustat $(1,646)$ and missing analyst forecast data from $\mathrm{I} / \mathrm{B} / \mathrm{E} / \mathrm{S}(13,971)$ over fiscal years of 2004-2014, the final long-term UK test sample is comprised of 5,156 observations. ${ }^{9}$ This sample is used to test the long-term effect of requiring an EP's signature in the UK, which is driven by the change in EPs' accountability. On the one hand, the effect of EP signature requirement on accountability should be as long as the requirement stays. On the other hand, the effect of EP signature requirement on the information asymmetry should be a one-time impact. The short-term effect of the EP signature on analysts' information environment should be driven by the change in the information asymmetry. Therefore, I next construct the UK sample to test the short-term effect of the requirement on the outcomes.

I use a balanced panel design to examine the short-term effect of the EP signature requirement on the analysts' information environment over fiscal years of 2008-2010. In particular, I use the last year of pre-signature requirement as a benchmark to compare against the first year of the post-signature requirement. Therefore, I use a balanced panel design by comparing U.K. firms in the last year before the implementation of the signature requirement to the same firms in the first year of the signature requirement. This design can minimize confounding effects that may lead to the association between the EP signature requirement and analysts'

\footnotetext{
${ }^{7}$ Please refer to the details of variable measurements in the Appendex.

${ }^{8}$ The analysts' forecasts are the last forecasts made by analysts before the current period earnings announcement date and after the previous period earnings announcement date in the detailed file of $\mathrm{I} / \mathrm{B} / \mathrm{E} / \mathrm{S}$.

${ }^{9}$ Although I use financial data for sample firms up to fiscal year end 2015, my samples end 2014 because the calculation of discretionary accruals need one year lead financial data (Francis et al. 2005).
} 
information environment, because the comparison is made between a firm itself from the pre-EP signature period to the post-EP signature period. To satisfy the terms of the balanced panel design, I require the firms to have data in both the year prior to the signature and in the first year of the signature requirement (Carcello and Li 2013). These selection criteria lead to a final short-term UK test sample of 756 observations.

To address the concern about the confounding effects that may lead to the changes in the economic outcomes around the passage of the EP signature requirement, I construct control samples. I compare the U.K. firms with firms from the U.S. that has not adopted the EP signature requirement yet. I match the UK firms with U.S. firms based on industry, fiscal year, and size. I also require the long-term and short-term control sample firms meet the same requirements as those used to select long-term and short-term UK test samples. These procedures lead to a matched long-term (short-term) U.S. control sample of 5,156 (756) observations. ${ }^{10}$

Table 1. Sample Determination

Samples used to the effects of the EP signature requirement

All Compustat UK test group firms for the period of 2004 to 2014 Less:

Firm-years in the utilities and financial industry

(SIC 4813, SIC 4900-4999, and SIC 6000-6999)

Less missing observations:

Missing financial data from Compustat

Missing analysts' forecast data from IBES

Final sample (long-term) ${ }^{1}$

\subsection{Descriptive Statistics}

Tables 2 and 3 report descriptive statistics for the variables of interest over short term (i.e., 2008-2010) and long term (i.e., 2004-2014), respectively. Continuous variables are winsorized at the $1 \%$ and $99 \%$ levels to minimize the effects of outliers. All variables are presented as scaled in regression models. The Appendix describes all the variables used in my analyses. In both tables, panel A (B) presents the descriptive statistics for observations of the UK test sample in the pre-EP (post-EP) signature period, and panel C (D) presents the descriptive statistics for observations of the US control sample in the pre-EP(post-EP) signature period.

Table 2. Descriptive Statistics for the Short-Term UK Test Sample and US Control Sample

Panel A: UK test sample firms in the pre-signature period (2008-2009)

\begin{tabular}{|c|c|c|c|c|c|}
\hline $\begin{array}{l}\text { Variable }^{1} \\
(\mathrm{~N}=378)\end{array}$ & Mean & Std. Dev. & Q1 & Median & Q3 \\
\hline IS & 0.656 & 0.324 & 0.436 & 0.801 & 0.927 \\
\hline $\mathrm{FE}$ & 0.005 & 0.032 & 0.000 & 0.004 & 0.006 \\
\hline Dispersion & 0.037 & 0.074 & 0.006 & 0.016 & 0.035 \\
\hline AnCov & 2.071 & 0.661 & 1.609 & 2.079 & 2.602 \\
\hline SIZE & 6.726 & 1.760 & 5.410 & 6.595 & 7.927 \\
\hline ROA & 0.040 & 0.124 & 0.007 & 0.053 & 0.092 \\
\hline $\mathrm{MB}$ & 1.678 & 3.671 & 0.653 & 1.197 & 2.290 \\
\hline Horizon & 2.478 & 0.705 & 1.946 & 2.565 & 2.996 \\
\hline Leverage & 0.601 & 0.217 & 0.462 & 0.616 & 0.737 \\
\hline Intangible & 0.319 & 0.262 & 0.089 & 0.263 & 0.477 \\
\hline ABAQ & 0.119 & 0.125 & 0.042 & 0.082 & 0.157 \\
\hline \multicolumn{6}{|c|}{ Panel B: UK test sample firms in the post-signature period (2009-2010) } \\
\hline $\begin{array}{l}\text { Variable }^{1} \\
(\mathrm{~N}=378)\end{array}$ & Mean & Std. Dev. & Q1 & Median & Q3 \\
\hline IS & 0.633 & 0.344 & 0.304 & 0.766 & 0.938 \\
\hline $\mathrm{FE}$ & 0.003 & 0.032 & 0.001 & 0.004 & 0.005 \\
\hline Dispersion & 0.030 & 0.054 & 0.006 & 0.013 & 0.031 \\
\hline AnCov & 2.138 & 0.664 & 1.609 & 2.197 & 2.708 \\
\hline SIZE & 6.731 & 1.763 & 5.334 & 6.601 & 7.859 \\
\hline ROA & 0.036 & 0.094 & 0.009 & 0.039 & 0.075 \\
\hline $\mathrm{MB}$ & 1.860 & 3.962 & 0.972 & 1.610 & 2.797 \\
\hline Horizon & 2.533 & 0.725 & 1.946 & 2.565 & 3.045 \\
\hline Leverage & 0.588 & 0.227 & 0.444 & 0.580 & 0.730 \\
\hline Intangible & 0.283 & 0.224 & 0.082 & 0.251 & 0.436 \\
\hline ABAQ & 0.110 & 0.105 & 0.035 & 0.084 & 0.138 \\
\hline
\end{tabular}

${ }^{10}$ Untabulated sample industry and fiscal year distributions suggest to control for industry and year in my analyses. 
Panel C: US control sample firms in the pre-signature period (2008-2009)

\begin{tabular}{|c|c|c|c|c|c|}
\hline $\begin{array}{l}\text { Variable }^{1} \\
(\mathrm{~N}=378)\end{array}$ & Mean & Std. Dev. & Q1 & Median & Q3 \\
\hline IS & 0.767 & 0.264 & 0.750 & 0.867 & 0.926 \\
\hline $\mathrm{FE}$ & 0.009 & 0.051 & 0.000 & 0.005 & 0.006 \\
\hline Dispersion & 0.071 & 0.148 & 0.010 & 0.030 & 0.070 \\
\hline AnCov & 1.994 & 0.592 & 1.609 & 1.946 & 2.485 \\
\hline SIZE & 6.721 & 1.770 & 5.644 & 6.841 & 8.132 \\
\hline ROA & -0.002 & 0.184 & -0.033 & 0.043 & 0.093 \\
\hline MB & 2.040 & 3.410 & 0.945 & 1.608 & 2.784 \\
\hline Horizon & 2.421 & 0.641 & 2.079 & 2.708 & 3.091 \\
\hline Leverage & 0.516 & 0.244 & 0.331 & 0.511 & 0.667 \\
\hline Intangible & 0.195 & 0.216 & 0.018 & 0.116 & 0.308 \\
\hline ABAQ & 0.268 & 0.250 & 0.088 & 0.198 & 0.364 \\
\hline \multicolumn{6}{|c|}{ Panel D: US control sample firms in the post-signature period (2009-2010) } \\
\hline $\begin{array}{l}\text { Variable }^{1} \\
(\mathrm{~N}=378)\end{array}$ & Mean & Std. Dev. & Q1 & Median & Q3 \\
\hline IS & 0.706 & 0.223 & 0.772 & 0.879 & 0.932 \\
\hline $\mathrm{FE}$ & 0.008 & 0.028 & 0.000 & 0.004 & 0.005 \\
\hline Dispersion & 0.061 & 0.121 & 0.010 & 0.030 & 0.060 \\
\hline AnCov & 2.029 & 0.627 & 1.609 & 1.946 & 2.485 \\
\hline SIZE & 6.763 & 1.785 & 5.680 & 6.878 & 8.205 \\
\hline ROA & 0.000 & 0.173 & -0.021 & 0.032 & 0.078 \\
\hline MB & 2.615 & 3.755 & 1.280 & 1.969 & 3.234 \\
\hline Horizon & 2.584 & 0.646 & 2.398 & 2.890 & 3.219 \\
\hline Leverage & 0.503 & 0.246 & 0.320 & 0.498 & 0.649 \\
\hline Intangible & 0.195 & 0.208 & 0.021 & 0.125 & 0.316 \\
\hline ABAQ & 0.245 & 0.251 & 0.079 & 0.179 & 0.344 \\
\hline
\end{tabular}

Panel E: Comparison between UK and US firms from the pre- to post-EP signature period.

\begin{tabular}{|c|c|c|c|c|c|c|}
\hline $\begin{array}{l}\text { Variable } \\
(\mathrm{N}=378)\end{array}$ & $\begin{array}{l}\text { UK } \\
\text { Diff. in Mean } \\
\text { (1) }\end{array}$ & $\begin{array}{l}\text { US } \\
\text { Diff. in Mean } \\
\text { (2) }\end{array}$ & $\begin{array}{l}\text { UK-US } \\
\text { Diff-in-diff } \\
(3)=(1)-(2)\end{array}$ & $\begin{array}{l}\text { UK } \\
\text { Diff. in Median } \\
\text { (4) }\end{array}$ & $\begin{array}{l}\text { US } \\
\text { Diff. in Median } \\
\text { (5) }\end{array}$ & $\begin{array}{l}\text { UK-US } \\
\text { Diff-in-diff } \\
(6)=(4)-(5) \\
\end{array}$ \\
\hline IS & -0.023 & $-0.061 *$ & 0.038 & -0.035 & $0.012 * * *$ & $-0.047 * *$ \\
\hline $\mathrm{FE}$ & -0.002 & -0.001 & $-0.001 * *$ & 0.000 & $-0.001 * * *$ & 0.001 \\
\hline Dispersion & -0.007 & -0.010 & 0.003 & -0.003 & 0.000 & $-0.003^{*}$ \\
\hline AnCov & 0.067 & $0.035^{*}$ & $0.032 * * *$ & 0.118 & 0.000 & 0.118 \\
\hline SIZE & 0.005 & 0.042 & -0.037 & 0.006 & 0.037 & -0.031 \\
\hline $\mathrm{ROA}$ & $-0.004 * * *$ & 0.002 & $-0.006 * * *$ & $-0.014^{*}$ & $-0.011 * * *$ & -0.003 \\
\hline MB & 0.182 & $0.575 * * *$ & $-0.393 * *$ & $0.413 * * *$ & $0.361 * * *$ & 0.052 \\
\hline Horizon & 0.055 & 0.163 & $-0.108 * *$ & 0.000 & $0.182^{*}$ & $-0.182 * *$ \\
\hline Leverage & -0.013 & $-0.013 *$ & 0.000 & -0.036 & $-0.013^{* *}$ & $-0.023^{*}$ \\
\hline Intangible & $-0.036^{*}$ & $0.000 *$ & $-0.036 * *$ & -0.012 & 0.009 & $-0.021^{* *}$ \\
\hline ABAQ & -0.009 & $-0.023 *$ & 0.014 & 0.002 & $-0.019 * *$ & 0.021 \\
\hline
\end{tabular}

Panel A (C) and B (D) report the descriptive statistics for the UK (US) test (control) sample in the pre- and post-EP signature periods, respectively.

Panel E reports the differences in means and median of variables used in the regression analyses for the UK and the US samples from pre- to post-EP signature window. Column (1) and (2) report the differences in the mean values of variables used in the regressions for the UK and US firms, respectively, from pre- to post-EP signature period. Column (3) is the difference between columns (1) and (2). Column (4) and (5) report the differences in the medians of variables used in the regressions for the UK and US firms, respectively, from pre- to post-EP signature period. Column (6) is the difference between columns (4) and (5).

$*, * * * * *$ indicate that the mean (median) is significantly different at the $0.10,0.05$, and 0.01 levels respectively, using a t-test of means (Wilcoxon Rank Sums test).

${ }^{1}$ See Appendix A for variable definitions

Panels A and B of Table 2 show that the mean values of information asymmetry (IS), analysts' forecast errors $(F E)$, and analysts' forecast dispersion (Dispersion) are $0.656,0.005$, and 0.037 in the pre-EP signature period, respectively, and are $0.633,0.003$, and 0.030 in the post-EP signature period, respectively, for the UK test sample firms over 2008 to 2010. UK firms experience a decline in the profitability in the first year of the post-EP signature period compared to the last year of the pre-EP signature period: the mean value of profitability $(R O A)$ is $0.040(0.036)$ in the pre- (post-) EP signature period. The median value of growth $(M B)$ is $1.197(1.610)$ in the 
pre- (post-) EP signature period, suggesting that there is a significant increase in growth in the first year of the post-EP signature period compared to the last year of the pre-EP signature period. The UK firms also experience a slight decrease in intangible assets from the pre-EP signature period to the post-EP signature period. There is no significant change in other control variables when comparing the last year of the pre-EP signature period to the first year of the post-EP signature period.

Panels C and D of Table 2 show that the median values of information asymmetry (IS), analysts' forecast errors $(F E)$, and analysts' forecast dispersion (Dispersion) are $0.867,0.005$, and 0.030 in the pre-EP signature period respectively, and are $0.879,0.004$, and 0.030 in the post-EP signature period, respectively, for the U.S. control sample firms from 2008 to 2010 . These results indicate that the U.S. firms experience an increase in the information asymmetry and a decrease in analysts' forecast errors in the post-EP signature period compared to the pre-EP signature period, and these changes are statistically significant at 0.01 levels. The mean values of log values of the number of analysts' coverage (AnCov) are 1.994 and 2.029 in the pre- and post-signature period, respectively, indicating that the number of analysts following a firm significantly $(\mathrm{P}$-value $<0.1)$ increase in the post-EP signature period compared with the pre-EP signature period. Results in Panel C and D of Table 2 also show that the U.S. firms had significant increases in growth $(M B, \mathrm{P}$-value $<0.01)$ and accruals quality $(A B A Q$, $\mathrm{P}$-value $<0.1)$ as well as a significant decrease in leverage (Leverage, $\mathrm{P}$-value $<0.1$ ) in the post-EP signature period compared with the pre-EP signature period.

I then compare the differences in changes of mean and median values of variables for the UK test firms to those for the U.S. control firms from pre- to post-EP signature period, which are reported in Panel E of Table 2. Columns 1 (2) and 4 (5) report the differences in mean and median values of variables, respectively, for the UK (US) sample firms from the pre- to post- EP signature period. Column 3 (6) is the difference between columns 1 (4) and 2 (5). I find that the UK test sample firms have significantly more decline in the median value of $I S$ and marginally significant more decrease in the mean value of Dispersion than US control firms from the pre- to post-EP signature period. The UK test sample firms also have significantly more increase in analysts' coverage than the US control firms from the pre- to post-EP signature period. The UK test sample firms experience a decreases in profitability $(R O A, \mathrm{P}$-value $<0.01)$ from the pre- to post-EP signature period, but US control sample firms do not. The US control firms have a significant increase in the growth rate $(M B, \mathrm{P}$-value $<0.01)$ from the pre- to post-EP signature period, but the UK firms do not. The UK firms experience less increase in forecast horizon but more decease in intangible assets than the US firms from the pre- to post-EP signature period. These differences in control variables between the UK and US firms suggest that the changes in the economic characteristics do not likely drive the changes in analysts' information environment for the UK firms.

Table 3. Descriptive Statistics for the Long-Term UK Test Sample and US Control Sample

Panel A: UK test sample firms in the pre-signature period (2004-2009)

\begin{tabular}{|c|c|c|c|c|c|}
\hline $\begin{array}{l}\text { Variable }^{1} \\
(\mathrm{~N}=2,580)\end{array}$ & Mean & Std. Dev. & Q1 & Median & Q3 \\
\hline IS & 0.653 & 0.330 & 0.416 & 0.800 & 0.921 \\
\hline $\mathrm{FE}$ & 0.010 & 0.056 & 0.001 & 0.004 & 0.006 \\
\hline Dispersion & 0.034 & 0.067 & 0.007 & 0.015 & 0.035 \\
\hline AnCov & 1.474 & 0.783 & 0.693 & 1.099 & 2.079 \\
\hline SIZE & 5.765 & 2.117 & 4.265 & 5.506 & 7.020 \\
\hline ROA & 0.026 & 0.170 & 0.004 & 0.050 & 0.097 \\
\hline $\mathrm{MB}$ & 2.764 & 4.170 & 1.104 & 1.977 & 3.299 \\
\hline Horizon & 2.625 & 0.777 & 1.946 & 2.639 & 3.219 \\
\hline Leverage & 0.543 & 0.239 & 0.372 & 0.538 & 0.692 \\
\hline Intangible & 0.268 & 0.301 & 0.030 & 0.162 & 0.408 \\
\hline ABAQ & 0.143 & 0.149 & 0.044 & 0.095 & 0.189 \\
\hline
\end{tabular}


Panel B: UK test sample firms in the post-signature period (2009-2014)

\begin{tabular}{|c|c|c|c|c|c|}
\hline $\begin{array}{l}\text { Variable }^{1} \\
(\mathrm{~N}=2,576)\end{array}$ & Mean & Std. Dev. & Q1 & Median & Q3 \\
\hline IS & 0.637 & 0.346 & 0.326 & 0.786 & 0.937 \\
\hline FE & 0.008 & 0.061 & 0.001 & 0.003 & 0.005 \\
\hline Dispersion & 0.035 & 0.066 & 0.006 & 0.014 & 0.034 \\
\hline AnCov & 1.722 & 0.842 & 1.099 & 1.609 & 2.398 \\
\hline SIZE & 5.921 & 2.178 & 4.377 & 5.743 & 7.310 \\
\hline ROA & 0.006 & 0.199 & -0.002 & 0.040 & 0.087 \\
\hline MB & 2.640 & 4.165 & 0.978 & 1.740 & 3.134 \\
\hline Horizon & 2.578 & 0.699 & 1.946 & 2.639 & 3.091 \\
\hline Leverage & 0.514 & 0.249 & 0.340 & 0.499 & 0.673 \\
\hline Intangible & 0.288 & 0.282 & 0.051 & 0.216 & 0.453 \\
\hline ABAQ & 0.129 & 0.134 & 0.042 & 0.093 & 0.170 \\
\hline \multicolumn{6}{|c|}{ Panel C: US control sample firms in the pre-signature period (2004-2009) } \\
\hline $\begin{array}{l}\text { Variable }^{1} \\
(\mathrm{~N}=2,580)\end{array}$ & Mean & Std. Dev. & $\overline{\mathrm{Q} 1}$ & Median & Q3 \\
\hline IS & 0.764 & 0.249 & 0.751 & 0.858 & 0.919 \\
\hline FE & 0.011 & 0.060 & 0.001 & 0.005 & 0.007 \\
\hline Dispersion & 0.083 & 0.190 & 0.010 & 0.030 & 0.060 \\
\hline AnCov & 1.706 & 0.737 & 1.099 & 1.609 & 2.303 \\
\hline SIZE & 5.766 & 2.045 & 5.293 & 6.675 & 8.054 \\
\hline ROA & -0.009 & 0.229 & -0.009 & 0.035 & 0.089 \\
\hline MB & 2.786 & 3.893 & 1.298 & 2.076 & 3.428 \\
\hline Horizon & 2.612 & 0.696 & 2.079 & 2.639 & 3.045 \\
\hline Leverage & 0.534 & 0.274 & 0.323 & 0.520 & 0.720 \\
\hline Intangible & 0.185 & 0.242 & 0.010 & 0.081 & 0.279 \\
\hline ABAQ & 0.293 & 0.277 & 0.097 & 0.213 & 0.398 \\
\hline \multicolumn{6}{|c|}{ Panel D: US control sample firms in the post-signature period (2009-2014) } \\
\hline $\begin{array}{l}\text { Variable }^{1} \\
(\mathrm{~N}=2,576)\end{array}$ & Mean & Std. Dev. & Q1 & Median & Q3 \\
\hline IS & 0.779 & 0.215 & 0.774 & 0.878 & 0.935 \\
\hline $\mathrm{FE}$ & 0.012 & 0.056 & 0.002 & 0.004 & 0.006 \\
\hline Dispersion & 0.085 & 0.177 & 0.010 & 0.030 & 0.070 \\
\hline AnCov & 1.822 & 0.789 & 1.099 & 1.792 & 2.485 \\
\hline SIZE & 5.941 & 2.137 & 5.555 & 7.000 & 8.425 \\
\hline ROA & -0.025 & 0.256 & -0.018 & 0.028 & 0.076 \\
\hline MB & 2.878 & 4.527 & 1.155 & 1.930 & 3.422 \\
\hline Horizon & 2.627 & 0.698 & 1.946 & 2.639 & 3.219 \\
\hline Leverage & 0.543 & 0.273 & 0.336 & 0.530 & 0.726 \\
\hline Intangible & 0.188 & 0.239 & 0.010 & 0.089 & 0.295 \\
\hline ABAQ & 0.276 & 0.275 & 0.092 & 0.205 & 0.391 \\
\hline
\end{tabular}

Panel E: Comparison between UK and US firms from the pre- to post-EP signature period.

\begin{tabular}{|c|c|c|c|c|c|c|}
\hline $\begin{array}{l}\text { Variable } \\
(\mathrm{N}=2,580)\end{array}$ & $\begin{array}{l}\text { UK } \\
\text { Diff. in Mean } \\
\text { (1) } \\
\end{array}$ & $\begin{array}{l}\text { US } \\
\text { Diff. in Mean } \\
\text { (2) }\end{array}$ & $\begin{array}{l}\text { UK-US } \\
\text { Diff-in-diff } \\
(3)=(1)-(2) \\
\end{array}$ & $\begin{array}{l}\text { UK } \\
\text { Diff. in Median } \\
\text { (4) }\end{array}$ & $\begin{array}{l}\text { US } \\
\text { Diff. in Median } \\
\text { (5) }\end{array}$ & $\begin{array}{l}\text { UK-US } \\
\text { Diff-in-diff } \\
(6)=(4)-(5)\end{array}$ \\
\hline IS & $-0.016^{*}$ & $0.015^{* * *}$ & $-0.031 * * *$ & -0.014 & $0.020 * * *$ & $-0.034 * * *$ \\
\hline $\mathrm{FE}$ & -0.002 & 0.001 & $-0.003 * * *$ & -0.001 & -0.001 & 0.000 \\
\hline Dispersion & 0.001 & 0.002 & $-0.001 * *$ & $-0.001 * * *$ & 0.000 & $-0.001 * *$ \\
\hline AnCov & $0.248 * * *$ & $0.116 * * *$ & $0.132 * *$ & $0.510 * * *$ & $0.183 * * *$ & $0.327 * * *$ \\
\hline SIZE & $0.156 * * *$ & $0.175 * * *$ & -0.019 & $0.237 * * *$ & $0.325 * * *$ & -0.088 \\
\hline ROA & $-0.020 * * *$ & $-0.016 * * *$ & -0.004 & $-0.010 * * *$ & $-0.007 * * *$ & -0.003 \\
\hline MB & -0.124 & $0.092 * *$ & $-0.216 * *$ & $-0.237 * * *$ & $-0.146 * * *$ & $-0.091 * *$ \\
\hline Horizon & $-0.047 * * *$ & 0.015 & $-0.062 * * *$ & 0.000 & 0.000 & 0.000 \\
\hline Leverage & $-0.029 * * *$ & $0.009 * * *$ & $-0.038 * *$ & $-0.039 * * *$ & $0.010 * *$ & $-0.049 * * *$ \\
\hline Intangible & $0.020 * * *$ & 0.003 & $0.017 * * *$ & $0.054 * * *$ & $0.008^{*}$ & $0.046 * * *$ \\
\hline ABAQ & $-0.014 * * *$ & $-0.017 * *$ & 0.003 & $-0.002 * *$ & $-0.008 * *$ & 0.006 \\
\hline
\end{tabular}

Panel A (C) and B (D) report the descriptive statistics for the UK (US) test (control) sample in the pre- and post-EP signature periods, respectively.

Panel E reports the differences in means and medians of variables used in the regression analyses for the UK and the US samples from pre- to post-EP signature window. Column (1) and (2) report the differences in the mean values of variables used in the regressions for the UK and US firms, respectively, from pre- to post-EP signature period. Column (3) is the difference between columns (1) and (2). Column (4) and (5) report the differences in 
the medians of variables used in the regressions for the UK and US firms, respectively, from pre- to post-EP signature period. Column (6) is the difference between columns (4) and (5).

$*, * *, * * *$ indicate that the mean (median) is significantly different at the $0.10,0.05,0.01$ level respectively, using a two-tiled t-test of means (Wilcoxon Rank Sums test).

${ }^{1}$ See Appendix A for variable definitions

Panels A and B of Table 3 show that the UK test firms have a marginally significant (P-value $<0.1$ ) decrease in the mean values of information asymmetry in the post-EP signature period compared with the pre-EP signature period. These results support my hypotheses 1 over the long-term (i.e., 2004-2014). The UK test sample firms also experience significant increases in analyst coverage (AnCov, P-value $<0.01)$, size (Size, P-value < 0.01), intangible assets (Intangible, $\mathrm{P}$-value $<0.01)$, and accruals quality $(A B A Q, \mathrm{P}$-value $<0.01)$, but experience decreases in mean values of profitability $(R O A$, $\mathrm{P}$-value $<0.01)$, forecast horizon (Horizon, $\mathrm{P}$-value $<0.01)$, and leverage (Leverage, $\mathrm{P}$-value $<0.01$ ) in the post-EP signature period compared with pre-EP signature period.

Panels C and D of Table 3 show that, for the U.S. control firms, the changes in the mean values of variables in the regressions over the long-term period (i.e., 2004-2014) are similar to those over the short-term period (i.e., 2008-2010). The U.S. control firms experienced a significant increase in the information asymmetry (P-value < $0.01)$, analyst coverage $(\mathrm{P}$-value $<0.01)$, size $(\mathrm{P}$-value $<0.01)$, growth $(\mathrm{P}$-value $<0.01)$, leverage $(\mathrm{P}$-value $<$ $0.01)$, accruals quality $(\mathrm{P}$-value $<0.05)$, and leverage $(\mathrm{P}$-value $<0.01)$ in the post-EP signature period compared to the pre-EP signature period.

Similar to my analyses for the differences between the two samples (i.e., test vs. control) over the short-term period, the analyses for two samples over the long-term period show that the UK test sample firms experience more decline in information asymmetry $(I S, \mathrm{P}$-values $<0.01)$, and additional decreases in analysts forecast errors (FE, $\mathrm{P}$-value $<0.01)$ and forecast dispersion (Dispersion, $\mathrm{P}$-values $<0.05)$ than the US firms from the pre- to post-EP signature period. The UK firms experience greater increase in analyst coverage (AnCov, $\mathrm{P}$-value <0.05) than the US firms from the pre-EP to the post-EP signature period. The US firms have more increase in the growth $(M B, \mathrm{P}$-value $<0.05)$, forecast horizon (Horizon, $\mathrm{P}$-value $<0.01)$, and leverage $(\mathrm{P}$-value $<0.05)$, as well as less increase in intangible assets (P-value $<0.01)$ than the UK firms from the pre- to post-EP signature period.

Table 4. Pearson above (Spearman below) Matrices for the UK Test Samples

UK test sample (over 2004-2014) used to test H1-H3

\begin{tabular}{|c|c|c|c|c|c|c|c|c|c|c|c|c|}
\hline $\begin{array}{l}\text { Variable }^{1} \\
(n=5,156)\end{array}$ & 1 & 2 & 3 & 4 & 5 & 6 & 7 & 8 & 9 & 10 & 11 & 12 \\
\hline $1 \mathrm{IS}$ & & -0.100 & 0.263 & -0.021 & 0.492 & 0.419 & 0.211 & 0.105 & 0.006 & 0.080 & -0.040 & -0.050 \\
\hline $2 \mathrm{FE}$ & 0.176 & & 0.098 & -0.012 & -0.120 & -0.097 & -0.245 & -0.041 & 0.057 & 0.021 & -0.020 & 0.033 \\
\hline 3 Dispersion & 0.489 & 0.101 & & 0.002 & 0.236 & 0.316 & 0.001 & -0.014 & -0.007 & 0.011 & -0.142 & -0.047 \\
\hline 4 POST & 0.009 & 0.008 & -0.042 & & 0.164 & 0.052 & -0.035 & -0.018 & -0.042 & -0.059 & 0.025 & -0.050 \\
\hline $5 \mathrm{AnCov}$ & 0.573 & -0.046 & 0.380 & 0.167 & & 0.803 & 0.240 & 0.096 & -0.065 & 0.268 & -0.009 & -0.167 \\
\hline 6 Size & 0.476 & -0.054 & 0.430 & 0.057 & 0.795 & & 0.285 & -0.038 & -0.057 & 0.369 & -0.037 & -0.183 \\
\hline 7 ROA & 0.208 & -0.182 & 0.030 & -0.045 & 0.245 & 0.178 & & -0.025 & -0.022 & 0.069 & 0.008 & -0.048 \\
\hline $8 \mathrm{MB}$ & 0.206 & -0.002 & 0.044 & -0.050 & 0.199 & 0.030 & 0.325 & & 0.011 & 0.063 & -0.028 & 0.002 \\
\hline 9 Horizon & 0.014 & 0.018 & -0.008 & -0.033 & -0.053 & -0.044 & -0.011 & 0.012 & & 0.002 & 0.003 & 0.037 \\
\hline 10 Leverage & 0.101 & -0.038 & 0.094 & -0.063 & 0.283 & 0.415 & -0.006 & 0.099 & 0.000 & & -0.106 & 0.057 \\
\hline 11 Intangible & -0.012 & 0.011 & -0.189 & 0.067 & 0.078 & 0.031 & 0.048 & 0.027 & -0.005 & -0.030 & & -0.013 \\
\hline 12 ABAQ & -0.080 & 0.000 & -0.064 & -0.027 & -0.144 & -0.163 & 0.025 & 0.012 & 0.037 & 0.042 & -0.054 & \\
\hline
\end{tabular}

Bolded estimates are significant at the 5 percent level, based on a two-tiled t-test.

${ }^{1}$ See Appendix A for variable definitions

Table 4 reports the Pearson (above the diagonal) and Spearman (below the diagonal) correlations among the model variables used to test $\mathrm{H} 1-\mathrm{H} 3$. The dependent variables (IS, FE, and Dispersion) are significantly positively associated with each other, which are consistent with my expectation. The Spearman correlation coefficient between POST and Dispersion is -0.042 (P-value < 0.01), consistent with H3. ${ }^{11}$ All statistically significant correlations between variables are less than 0.5 with the exception of Size and AnCov (correlation of 0.803 , P-value $<0.01$ ). This is not surprising because larger firms are expected to have high analyst coverage. ${ }^{12}$

\footnotetext{
${ }^{11}$ The Spearman correlation coefficient is defined as the Pearson correlation coefficient between the ranked variables and is a nonparametric measure of statistical dependence between two variables.

${ }^{12}$ I therefore use the fitted value of $A n \operatorname{Cov}$ in my regression analyses rather than the raw value of $A n \operatorname{Cov}$ in the sensitivity analyses.
} 
Thus, these correlation results indicate that multicollinearity should not compromise inferences.

\section{Results and Analyses}

\subsection{Tests of EP Signature Requirement}

Panels A and B of Table 5 report the panel OLS regression results with clustering the standard errors by firm to account for the possible correlation of regression residuals (Petersen 2009). Equations (1) and (2) test the effects of the EP signature requirement on information asymmetry $(I S)$ as well as analysts' forecast errors $(F E)$ and forecast dispersion (Dispersion) in the UK. In Panel A of Table 5, when using a balanced panel design to test $\mathrm{H} 1-\mathrm{H} 3$ over a short period (i.e., 2008-2010), the adjusted R-squares are 0.337, 0.129, and 0.457 for the $I S, F E$, and Dispersion models, respectively, which are comparable with previous studies (Horton et al. 2013; Byard et al. 2011).

The estimated coefficients on POST, the variable capturing the EP signature effect, are -0.023 (P-value > 0.1), -0.011 (P-value $<0.05)$, and -0.008 ( $\mathrm{P}$-value $<0.05)$ for the information asymmetry $(I S)$, forecast errors $(F E)$, and dispersion (Dispersion) regressions, respectively, indicating that $F E$ and Dispersion decrease 0.011 unit and 0.008 unit, respectively, in the post-EP signature period compared to the pre-EP signature period. These findings suggest that following the implementation of the EP signature requirement, analysts' forecast errors and dispersion decrease, supporting my H2 and $\mathrm{H} 3$ over the period of 2008-2010.

The coefficient on AnCov in the IS regression is 0.222 ( $\mathrm{P}$-value < 0.01 ), the sign of which is consistent with my expectation and previous study (Horton et al. 2013). The coefficient on $R O A$ is significant in the $I S(0.414$, $\mathrm{P}$-value < 0.01$)$ and $F E(0.279$, P-value < 0.01$)$ regressions. The coefficient on Size is -0.011 (P-value < 0.01$)$ in the Dispersion regression,

In Panel B of Table 5, when I test H1-H3 over a long period (i.e., 2004-2014), the estimated coefficients on POST, the variable capturing the EP signature effect, are -0.034 (P-value $<0.01),-0.007$ ( $\mathrm{P}$-value $<0.01$ ), and -0.004 (P-value $<0.01$ ) for the information asymmetry $(I S)$, forecast errors $(F E)$, and dispersion (Dispersion) regressions, respectively. These results indicate that following the implementation of the EP signature requirement, the information asymmetry, analysts' forecast errors, and analysts' forecast dispersion decrease by 0.034 units, 0.007 units, and 0.004 units, respectively, supporting my H1, H2, and $\mathrm{H} 3$ over the period of 2004-2014.

The coefficient on AnCov in the $I S$ regression is 0.202 (P-value $<0.01$ ), consistent with my expectation and previous study (Horton et al. 2013). The coefficients on Size, ROA, MB, Big4 in the IS regression are -0.014 (P-value < 0.01), 0.275 (P-value <0.01), 0.004 (P-value <0.01), and -0.037 (P-value <0.1), respectively, which are consistent with my expectation. Among the control variables in the $F E$ regression, the coefficients on $A n C o v$ $(-0.012$, P-value $<0.01)$, Size $(-0.003$, P-value $<0.05)$, ROA $(-0.058, \mathrm{P} \text {-value }<0.01)^{13}$, Intangible $(0.008$, $\mathrm{P}$-value $<0.1)$, Big4 $(-0.014$, P-value $<0.01)$ are statistically significant. Signs of coefficients of AnCov, Intangible, and Big4 are consistent with my expectation that firms followed by more analysts and audited by Big4 audit firms tend to have smaller analyst forecast errors while firms with a larger proportion of intangible assets are more likely to have larger analyst forecast errors. Similarly, among the control variables in the Dispersion regression, the coefficients on Size $(-0.010$, P-value $<0.01)$ and Intangible $(0.012$, P-value < 0.01$)$ are consistent with my expectation (Byard et al. 2011).

In sum, results in Table 5 support my $\mathrm{H} 2$ and $\mathrm{H} 3$ over a short period, as well as $\mathrm{H} 1, \mathrm{H} 2$, and $\mathrm{H} 3$ over a long period.

Table 5. Regressions of Analysts' Information Environment on the EP Signature Requirement for the UK Test Firms

$$
\begin{gathered}
I S, F E, \text { or Dispersion }= \\
\beta_{0}+\beta_{1} \text { POST }+\beta_{2} \text { AnCov }+\beta_{3} \text { Size }+\beta_{4} R O A+\beta_{5} M B+\beta_{6} \text { Horizon }+ \\
\beta_{7} \text { Leverage }+\beta_{8} \text { Intangible }+\beta_{9} \text { Big } 4+\beta_{10} A B A Q+\varepsilon
\end{gathered}
$$

\footnotetext{
${ }^{13}$ The sign of $R O A$ in the $F E$ regression over long-term is different from that over short-term. This result is not surprising because the short-term sample period overlapped with financial crisis and the current profitability had less inference about future performance of the firm. Analysts had larger FE for firms with higher ROA. However, over the long-term sample period, the quality of profitability improved and had better inference about future performance of the firms. Analysts were able to more accurately predict future earnings for firms with higher ROA.
} 
Panel A: Regression over the short-term (2008-2010)

\begin{tabular}{|c|c|c|c|c|c|c|c|}
\hline \multirow[b]{2}{*}{$\begin{array}{l}\text { Variable }^{1} \\
(\mathrm{~N}=756)\end{array}$} & \multirow[b]{2}{*}{ Prediction } & \multicolumn{2}{|l|}{$\underline{\mathrm{DV}=I S}$} & \multicolumn{2}{|l|}{$\underline{\mathrm{DV}=F E}$} & \multicolumn{2}{|c|}{$\underline{\mathrm{DV}=\text { Dispersion }}$} \\
\hline & & $\begin{array}{l}\text { Coefficient } \\
\text { (1) }\end{array}$ & $\begin{array}{l}\text { t-statistics } \\
\text { (2) }\end{array}$ & $\begin{array}{l}\text { Coefficient } \\
\text { (3) }\end{array}$ & $\begin{array}{l}\text { t-statistics } \\
(4)\end{array}$ & $\begin{array}{l}\text { Coefficient } \\
\text { (5) }\end{array}$ & $\begin{array}{l}\text { t-statistics } \\
\text { (6) }\end{array}$ \\
\hline Intercept & ? & 0.141 & 1.47 & 0.020 & 0.12 & $0.107 * *$ & 2.20 \\
\hline POST & $\mathrm{H} 1, \mathrm{H} 2, \& \mathrm{H} 3:-$ & -0.023 & -0.86 & $-0.011 * *$ & -2.46 & $-0.008 * *$ & -2.06 \\
\hline AnCov & $+/-/-$ & $0.222 * * *$ & 6.25 & 0.049 & 0.90 & 0.004 & 0.55 \\
\hline Size & - & 0.011 & 0.85 & -0.012 & -0.61 & $-0.011 * * *$ & -3.12 \\
\hline ROA & ? & $0.414 * * *$ & 3.50 & $0.279 * *$ & 2.69 & -0.019 & -0.41 \\
\hline MB & ? & 0.001 & 0.19 & -0.003 & -0.73 & 0.000 & 0.79 \\
\hline Horizon & + & -0.010 & -0.60 & 0.002 & 0.06 & 0.002 & 0.29 \\
\hline Leverage & $?$ & -0.025 & -0.33 & 0.139 & 1.22 & 0.019 & 0.98 \\
\hline Intangible & ? & -0.035 & -0.67 & 0.098 & 1.62 & -0.003 & -0.32 \\
\hline Big4 & - & 0.017 & 0.38 & -0.086 & -1.27 & -0.008 & -0.87 \\
\hline ABAQ & + & -0.145 & -1.52 & 0.000 & 0.00 & 0.004 & 0.15 \\
\hline Industry Fixed Effect & & Yes & & Yes & & Yes & \\
\hline Adjusted $\mathrm{R}^{2}$ & & 0.337 & & 0.129 & & 0.457 & \\
\hline \multicolumn{8}{|c|}{ Panel B: Regression over the long-term (2004-2014) } \\
\hline & & $\mathrm{DV}=\mathrm{IS}$ & & $\mathrm{DV}=\mathrm{FE}$ & & $\mathrm{DV}=$ Dispersion & \\
\hline $\begin{array}{l}\text { Variable }^{1} \\
(\mathrm{~N}=5,156)\end{array}$ & Prediction & $\begin{array}{l}\text { Coefficient } \\
\text { (1) }\end{array}$ & $\begin{array}{l}\text { t-statistics } \\
\text { (2) }\end{array}$ & $\begin{array}{l}\text { Coefficient } \\
\text { (3) }\end{array}$ & $\begin{array}{l}\text { t-statistics } \\
\text { (4) }\end{array}$ & $\begin{array}{l}\text { Coefficient } \\
\text { (5) }\end{array}$ & $\begin{array}{l}\text { t-statistics } \\
\text { (6) }\end{array}$ \\
\hline Intercept & $?$ & $0.314 * * *$ & 5.21 & $0.022 * *$ & 2.03 & 0.010 & 0.83 \\
\hline POST & H1, H2, \& H3: - & $-0.034 * * *$ & -2.74 & $-0.007 * *$ & -2.44 & $-0.004 *$ & -1.92 \\
\hline AnCov & $+/-/-$ & $0.202 * * *$ & 12.13 & $-0.012 * * *$ & -3.41 & 0.002 & 0.65 \\
\hline Size & - & $-0.014 * *$ & -2.93 & $-0.003 * *$ & -1.97 & $-0.010 * * *$ & -5.05 \\
\hline ROA & ? & $0.275 * * *$ & 5.20 & $-0.058 * * *$ & -4.09 & 0.006 & 0.53 \\
\hline MB & $?$ & $0.004 * * *$ & 3.30 & 0.000 & 0.60 & 0.000 & 1.24 \\
\hline Horizon & + & -0.003 & -0.34 & -0.002 & -0.83 & 0.000 & 0.10 \\
\hline Leverage & $?$ & -0.054 & -1.56 & -0.002 & -0.20 & -0.005 & -0.73 \\
\hline Intangible & $?$ & -0.024 & -0.91 & $0.008^{*}$ & 1.82 & $0.012 * * *$ & 3.01 \\
\hline Big 4 & - & $-0.037^{*}$ & -1.89 & $-0.014 * * *$ & -3.68 & -0.003 & -0.90 \\
\hline ABAQ & + & 0.031 & & -0.001 & -0.04 & 0.016 & 1.31 \\
\hline Industry Fixed Effect & & Yes & & Yes & & Yes & \\
\hline Year Fixed Effect & & Yes & & Yes & & Yes & \\
\hline Adjusted $\mathrm{R}^{2}$ & & 0.295 & & 0.0561 & & 0.3919 & \\
\hline
\end{tabular}

$*, * *, * * *$ indicates significant levels at the $0.10,0.05$, and 0.01 levels, respectively based on two-sided t-tests.

T-statistics are based on robust standard errors clustered by firms.

${ }^{1}$ See Appendix A for variable definitions.

\subsection{Robustness Tests and Additional Analyses}

\subsubsection{Difference-in-difference Approach}

To address the concerns about the confounding and omitted correlated variable problems, I use a control sample approach by comparing the change in the analysts' information environment for the UK test sample firms with the U.S. control sample firms over both the short-term (i.e., 2008-2010) and long-term (i.e., 2004-2014). I first match the U.S. firms with UK firms by industry and fiscal year. I then use the equations (1) and (2) to test the robustness of results of $\mathrm{H1}-\mathrm{H} 3$ by adding an indicator variable, $U K$, which is coded 1 for the UK test firms and 0 for the U.S. control firms, and an interaction term between UK and POST, UKPOST. The UKPOST is the variable of interest, capturing the difference in the change in the analysts' information environment between the UK test firms and the U.S. control firms.

In Panel A of Table 6, when using a balanced panel design and a control sample approach to test $\mathrm{H} 1-\mathrm{H} 3$ over a short period (i.e., 2008-2010), the estimated coefficients on POST are 0.034 (P-value < 0.01), 0.022 (P-value < 0.1 ), and -0.022 (P-value < 0.01$)$ for the information asymmetry $(I S)$, analysts' forecast errors $(F E)$, and analysts' forecast dispersion (Dispersion) regressions, respectively. These results suggest that there is an increase in the information asymmetry and analysts' forecast errors, and a decrease in analysts' forecast dispersion in the post-EP signature period compared with pre-EP signature period. The estimated coefficient on $U K$ are -0.132 (P-value <0.01), -0.017 (P-value >0.1), and -0.028 (P-value <0.01) for the information asymmetry $(I S)$, analysts' forecast errors $(F E)$, and analysts' forecast dispersion (Dispersion) regressions, respectively. These results indicate that the UK test firms experience lower information asymmetry, analysts' forecast errors, and analysts' forecast dispersion than the U.S. control firm over the period of 2008-2010. The estimated coefficient on the interested variable, UKPOST, are -0.059 (P-value <0.05), -0.014 ( $\mathrm{P}$-value > 0.1), and -0.009 ( $\mathrm{P}$-value < 0.05$)$ for 
the information asymmetry (IS), analysts' forecast errors $(F E)$, and analysts' forecast dispersion (Dispersion) regressions, respectively. These results show that the UK firms experience $0.059,0.014$, and 0.009 units more decline in the information asymmetry (IS), analysts' forecast errors $(F E)$, and analysts' forecast dispersion (Dispersion) than the U.S. firms from the pre-EP signature period to the post-EP signature period, supporting my H1-H3. The analyses for the control variables are similar to those presented in the Table 6.

In Panel B of Table 6, when comparing the changes in the analysts' information environment over a period of 2004-2014 between the UK test firms and the U.S. control firms, I find that the UK firms experience 0.062 and 0.033 units more decline in the information asymmetry $(I S)$ and analysts' forecast errors $(F E)$ than the U.S. firms from the pre-EP signature period to the post-EP signature period. For brevity, I do not repeat my analyses on the control variables.

Results in Table 6 support my H1 and $\mathrm{H} 3$ over the short-term period and my H1 and $\mathrm{H} 2$ over the long-term period when using the U.S. firms as control firms. These results are statistically and economically significant.

Table 6. Regressions of Analysts' Information Environment on the EP Signature Requirement for the UK Test Firms and US Control Firms

$$
\begin{aligned}
I S, F E, \text { or Dispersion }= & \beta_{0}+\beta_{1} \text { POST }+\beta_{2} U K+\beta_{3} U K P O S T+\beta_{4} A n C o v+\beta_{5} \text { Size }+\beta_{6} R O A+\beta_{7} M B+ \\
& \beta_{8} \text { Horizon }+\beta_{9} \text { Leverage }+\beta_{10} \text { Intangible }+\beta_{11} \text { Big } 4+\beta_{12} A B A Q+\varepsilon
\end{aligned}
$$

\begin{tabular}{|c|c|c|c|c|c|c|c|}
\hline $\begin{array}{l}\text { Variable }^{1} \\
(\mathrm{~N}=1,512)\end{array}$ & Prediction & $\begin{array}{l}\text { DV=IS } \\
\text { Coefficient } \\
\text { (1) }\end{array}$ & $\begin{array}{l}\text { t-statistics } \\
\text { (2) }\end{array}$ & $\begin{array}{l}\text { DV=FE } \\
\text { Coefficient } \\
\text { (3) }\end{array}$ & $\begin{array}{l}\text { t-statistics } \\
\text { (4) }\end{array}$ & $\begin{array}{l}\text { DV=Dispers } \\
\text { Coefficient } \\
(5)\end{array}$ & $\begin{array}{l}\text { t-statistics } \\
\text { (6) }\end{array}$ \\
\hline Intercept & $?$ & $0.358 * * *$ & 10.72 & 0.068 & 0.47 & 0.008 & 0.26 \\
\hline POST & $?$ & $0.034 * * *$ & 5.00 & $0.022 *$ & 1.83 & $-0.022 * * *$ & -6.94 \\
\hline UK & - & $-0.132 * * *$ & -6.56 & -0.017 & -0.85 & $-0.028 * * *$ & -4.66 \\
\hline UKPOST & H1, H2, \& H3: - & $-0.059 * *$ & -2.40 & -0.014 & -0.67 & $-0.009 * *$ & -2.30 \\
\hline AnCov & $+/-/-$ & $0.174 * * *$ & 21.68 & $-0.020 * *$ & -2.50 & $-0.017 * * *$ & -3.65 \\
\hline Size & - & $-0.011 * * *$ & -3.57 & -0.002 & -0.34 & $-0.015 * * *$ & -5.96 \\
\hline ROA & $?$ & $0.070 * * *$ & 2.80 & $0.083 * *$ & 2.58 & $-0.097 * * *$ & -5.25 \\
\hline MB & $?$ & 0.001 & 1.17 & -0.001 & -0.51 & 0.000 & -0.17 \\
\hline Horizon & + & 0.003 & 0.55 & -0.003 & -0.29 & 0.000 & 0.06 \\
\hline Leverage & $?$ & -0.003 & -0.14 & -0.007 & -0.22 & 0.011 & 0.99 \\
\hline Intangible & $?$ & -0.002 & -0.10 & 0.012 & 0.47 & $-0.039 * * *$ & -4.98 \\
\hline Big4 & - & 0.006 & 0.43 & 0.023 & 1.01 & 0.002 & 0.34 \\
\hline ABAQ & + & -0.011 & -0.64 & -0.032 & -1.17 & -0.016 & -1.55 \\
\hline Industry Fixed Effect & & Yes & & Yes & & Yes & \\
\hline Adjusted $\mathrm{R}^{2}$ & & 0.272 & & 0.018 & & 0.169 & \\
\hline
\end{tabular}

Panel A: Regression over the short-term (2008-2010)

\begin{tabular}{|c|c|c|c|c|c|c|c|}
\hline \multirow[b]{2}{*}{$\begin{array}{l}\text { Variable }^{1} \\
(\mathrm{~N}=10,312)\end{array}$} & \multirow[b]{2}{*}{ Prediction } & \multicolumn{2}{|l|}{$\mathrm{DV}=\mathrm{IS}$} & \multicolumn{2}{|l|}{$\mathrm{DV}=\mathrm{FE}$} & \multicolumn{2}{|c|}{$\mathrm{DV}=$ Dispersion } \\
\hline & & $\begin{array}{l}\text { Coefficient } \\
\text { (1) }\end{array}$ & $\begin{array}{l}\mathrm{t} \text {-s tatistics } \\
(2)\end{array}$ & $\begin{array}{l}\text { Coefficient } \\
\text { (3) }\end{array}$ & $\begin{array}{l}\text { t-statistics } \\
\text { (4) }\end{array}$ & $\begin{array}{l}\text { Coefficient } \\
(5)\end{array}$ & $\begin{array}{l}\text { t-s tatistics } \\
\text { (6) }\end{array}$ \\
\hline Intercept & $?$ & $0.444 * * *$ & 15.58 & 0.014 & 0.22 & $0.082 *$ & 1.81 \\
\hline POST & $?$ & $0.015 * * *$ & 4.47 & $0.021 * * *$ & 3.17 & $-0.009 * * *$ & -3.17 \\
\hline UK & - & $-0.096 * * *$ & -8.20 & 0.012 & 0.76 & $-0.028 * * *$ & -6.10 \\
\hline UKPOST & H1, H2, \& H3: - & $-0.062 * * *$ & -4.92 & $-0.033^{*}$ & -1.79 & 0.003 & 0.78 \\
\hline $\mathrm{AnCov}$ & $+/-/-$ & $0.171 * * *$ & 47.93 & $0.015 * * *$ & 2.66 & $-0.034 * * *$ & -9.74 \\
\hline Size & - & $-0.005 * * *$ & -3.88 & 0.000 & 0.04 & $-0.016 * * *$ & -9.42 \\
\hline ROA & $?$ & $0.038 * * *$ & 3.83 & $0.057 * * *$ & 3.70 & $-0.090 * * *$ & -8.04 \\
\hline MB & $?$ & 0.000 & 0.05 & 0.000 & 0.66 & 0.000 & -0.55 \\
\hline Horizon & + & 0.001 & 0.53 & $0.010 * *$ & 2.16 & 0.000 & -0.08 \\
\hline Leverage & $?$ & -0.008 & -1.01 & $-0.044 * * *$ & -2.67 & 0.007 & 0.87 \\
\hline Intangible & $?$ & -0.009 & -1.16 & -0.009 & -0.73 & $-0.037 * * *$ & -6.11 \\
\hline Big 4 & - & $-0.022 * * *$ & -3.66 & 0.012 & 1.14 & 0.003 & 0.69 \\
\hline ABAQ & + & $0.020 * *$ & 2.69 & -0.014 & -1.21 & -0.010 & -1.38 \\
\hline Industry Fixed Effect & & Yes & & Yes & & Yes & \\
\hline Year Fixed Effect & & Yes & & Yes & & Yes & \\
\hline Adjusted $\mathrm{R}^{2}$ & & 0.285 & & 0.009 & & 0.121 & \\
\hline
\end{tabular}

Panel B: Regression over the long-term (2004-2014)

$*, * *, * * *$ indicates significant levels at the $0.10,0.05$, and 0.01 levels, respectively based on two-sided t-tests. T-statistics are based on robust standard errors clustered by firms.

${ }^{1}$ See Appendix A for variable definitions. 


\subsubsection{Alternative Measure of Forecast Errors and Forecast Dispersion}

I compute forecast error $(F E)$ as the difference between analysts' forecast median and actual earnings-per-share, deflated by the share price at the beginning of the fiscal year. I then repeat my analyses related to the $F E$ regressions, the results of which are qualitatively similar to those reported in Tables $5 \& 6$.

I also compute the variable of Dispersion as the natural logarithm value of the forecast standard de viation and repeat my analyses related to Dispersion regressions. The results are qualitatively similar to those reported in Tables $5 \& 6$.

\subsubsection{SLS Regressions}

To account for the possibility that $A n C o v$ and $F E$ as well as AnCov and Dispersion are simultaneously determined, I first estimate $A n \operatorname{Cov}$ by regressing $A n \operatorname{Cov}$ on the firms' characteristics variables documented in previous literature (Lang and Lundholm 1996; Byard et al. 2011). I then repeat my analyses on $F E$ and Dispersion regressions using the estimated AnCov instead of raw value of AnCov. The results of these 2SLS regressions ( $F E$ and Dispersion) are qualitatively similar to those reported in Tables $5 \& 6$.

\section{Conclusion}

I investigate the economic consequences of requiring an EP's signature in the UK over a short-term and long-term. The SEC passed the PCAOB's proposal that mandates disclosing the EP's identity in the U.S. The benefits and costs of this rule is debatable. Although three studies (Carcello and Li 2013; Liu 2017; John, Liu, and Sunder 2017) provide evidence on the benefits of a similar rule (implementation of the EP signature requirement) in the UK over a short period, there is the lack of the evidence whether the benefits of disclosing the EP's identity hold over a long-term period. This study provides first hand empirical evidence on whether and the extent to which the implementation of the EP signature requirement benefits analysts information environment over long time.

Based on accountability and disclosure theories, my first, second, and third hypotheses predict that the implementation of the EP signature requirement is associated with a decrease in information asymmetry, analysts' forecast errors, and analysts' forecast dispersion in the UK. Consistent with my first, second, and third hypotheses, I find some evidence that the UK firms experienced significant declines in information asymmetry, analysts' forecast errors, and analysts' forecast dispersion in the post-EP signature period compared to the pre-EP signature period. These results hold to a battery of robustness tests such as employing different test periods and comparing the UK firms with the U.S. control firms over the same periods. The results of this paper indicate that the improvement in financial statement quality could last and the EPs devoted more efforts to the engagements in the post-signature period.

This study provides informative empirical evidence to support the PCAOB's decision on passing a similar requirement in the U.S.by showing that the EPs improved audit quality because of the increased accountability in the post-signature period, which benefits analysts over a short- and long-term period. The results are also useful to firms by showing that the disclosure of the EP's name may reduce information asymmetry. Moreover, the results aid investors who demand more information about the audit by showing that the implementation of the EP signature improves analysts' forecast performances.

\section{APPENDIX}

\section{Variable Definitions}

$I S=1-\rho$, the proxy for information asymmetry, which reflects the lack of analysts' consensus.

$\rho=\quad=$ the ratio of common uncertainty to overall uncertainty, $C / V$.

$C=S E-\frac{D}{n}$, common uncertainty across analysts. Here, $D$ is measured by the sample variance of the individual forecast $F C_{i}$ around the mean forecast $(\overline{F C})$; and $\mathrm{SE}$ is the square error in the mean forecast, which is measured as the square of the difference between earnings per share and the mean forecast, i.e., $(E P S-\overline{F C})^{2}$.

$V=$ overall uncertainty, which is measured by the mean of the squared differences between individual analysts' forecasts $\left(F C_{i}\right)$ and reported earnings per share $(E P S)$.

$F E=$ the absolute value of the difference between the analyst's last one-year-ahead forecasted earnings-per-share and the actual earnings-per-share reported by $\mathrm{I} / \mathrm{B} / \mathrm{E} / \mathrm{S}$, deflated by the absolute value of the actual earnings-per-share.

Dispersion = the standard deviation of one-year-ahead forecasted earnings-per-share deflated by the absolute value of the actual earnings-per-share. 
POST = 1 if a firm-year ends in April 2009 or after, 0 otherwise.

AnCov = analyst coverage, which is measured as the log value of sum of 1 and the total number of analysts who issue at least one annual earnings forecast for the firm-year. I use all analysts following a firm.

Size = natural logarithm value of the total assets in US dollar amount.

Horizon $=\log$ value of the number of the days between the forecast issuing date and the earnings announcement date.

$R O A=$ ratio of income before extraordinary items to the prior year-end total assets.

$M B$ = ratio of market-to-book of firmi.

Leverage $\quad=$ ratio of total liability to total assets.

Intangible $\quad=$ intangible assets deflated by the prior year-end total asset.

Big4 = 1 if the financial reports of firm $\mathrm{i}$ in the year $\mathrm{t}$ were audited by a Big Four auditor, 0 otherwise.

$A B A Q=$ absolute value of abnormal accruals, which is estimated by a modified Jones (1991) model. A larger value for $A B A Q$ implies a lower accounting information quality. First, I measure discretionary accruals as the difference between firms' actual accruals and the normal level of accruals. I cross-sectionally estimate the latter for each industry using the modified Jones (1991) model below: ${ }^{14}$

$$
\frac{T A_{t}}{A_{t-1}}=\rho_{0}+\rho_{1}\left(\frac{1}{A_{t-1}}\right)+\rho_{2}\left(\frac{\Delta S_{t}}{A_{t-1}}\right)+\rho_{3}\left(\frac{P P E_{t}}{A_{t-1}}\right)+\varepsilon_{t}
$$

where $T A$ is the earnings before extraordinary items and discontinued operations less the operating cash flows reported in the statement of cash flows in year $\mathrm{t}$; $S$ is the sales in the year $\mathrm{t}$; and $P P E$ is the gross of property, plant, and equipment. Then, I compute the absolute value of the estimated residuals, $A B A Q$, from the estimation of equation (3) as my proxy for the accruals quality. A larger value for $A B A Q$ implies a lower accounting information quality.

\section{Acknowledgements}

This paper is based on my dissertation at Florida Atlantic University. I am grateful to my dissertation committee (Mark Kohlbeck, Julia Higgs, Maya The venot, and Yy-Hyang Yuhn) for their helpful comments. I thank my discussant (Chuong Do) and participants at the workshop of the 2017 AAA International Section for their helpful comments. Earnings forecasts used in this paper are provided by $\mathrm{I} / \mathrm{B} / \mathrm{E} / \mathrm{S}$. All remaining errors are my own.

\section{References}

Amihud, Y., \& Mendelson, H. (1986). The effects of beta, bid-ask spread, residual risk and size on stock returns. The Journal of Finance, 479-486.

Aobdia, D., Lin, C., \& Petacchi, R. (2015). Capital market consequences of individual audit partners. The Accounting Review, 90(6), 2143-2176. https://doi.org/10.2308/accr-51054

Ashbaugh, H., \& Pincus, M. (2001). Domestic accounting standards, international accounting standards, and the predictability of earnings. Journal of Accounting Research, 39, 417-434. https://doi.org/10.1111/1475-679X.00020

Ashton, R. H. (1992). Effects of justification and a mechanical aid on judgement performance. Organizational Behavior and Human Decision Processes, 52, 292-306. https://doi.org/10.1016/0749-5978(92)90040-E

Azizkhani, M., Monroe, G. S., \& Shailer, G. (2013). Audit Partner tenure and cost of equity capital. Auditing: A Journal of Practice \& Theory, 32(1), 183-202. https://doi.org/10.2308/ajpt-50308

Bae, K-H, H. Tan, \& Welker, M. (2008). International GAAP differences: The impact on foreign analysts. The Accounting Review, 83, 593-628. https://doi.org/10.2308/accr.2008.83.3.593

\footnotetext{
${ }^{14}$ I use equation (3) to estimate cross-sectional discretionary accruals because this model does not contain as many data restrictions as other versions of the modified Jones model. Unlike the time-series method, the cross-sectional estimation method does not require lead and lag variables over many periods to be used to estimate the discretionary accruals. The time-series method creates a lot of noise in my analysis because my sample period is only three years and I test the EP signature effect from the last year prior to the implementation of the requirement to the first year with the implementation of the requirement.
} 
Barron, O., Kim, O., Lim, S., \& Stevens, D. (1998). Using analysts' forecasts to measure properties of analysts' information environment. The Accounting Review, 73, 421-433.

Barth, M., Kasznik, R., \& McNichols, M. (2001). Analyst coverage and intangible assets. Journal of Accounting Research, 39, 1-34. https://doi.org/10.1111/1475-679X.00001

Barth, M., Landsman, W., Lang, M., \& Williams, C. (2012). Are IFRS-based and US GAAP-based accounting amounts comparable? Journal of Accounting and Economics, 54, 68-93. https://doi.org/10.1016/j.jacceco.2012.03.001

Bhushan, R. (1989). Firm characteristics and analyst following. Journal of Accounting and Economics, 11, 255-274. https://doi.org/10.1016/0165-4101(89)90008-6

Byard, D., Li, Y., \& Yu, Y. (2011). The effect of mandatory IFRS adoption on financial analysts' information environment. Journal of Accounting Research, 49, 69-96. https://doi.org/10.1111/j.1475-679X.2010.00390.x

Carcello, J. V., \& Li, C. (2013). Costs and benefits of requiring an engagement partner signature: Recent experience in the United Kingdom. The Accounting Review, 88(5), 1511-1546. https://doi.org/10.2308/accr-50450

Carcello, J., \& Santore, R. (2015). Engagement Partner Identification: A Theoretical Analysis. Accounting Horizons, 29, 297-311. https://doi.org/10.2308/acch-50991

Chaiken, S. (1980). Heuristic versus systematic information processing and the use of source versus message cues in persuasion. Journal of Personality and Social Psychology, 752-766. https://doi.org/10.1037/0022-3514.39.5.752

Cohen, D., A. Dey, \& Lys, T. (2008). Real and accruals-based earnings management in the pre- and post-Sarbanes-Oxley eras. The Accounting Review, 83, 757-788. https://doi.org/10.2308/accr.2008.83.3.757

Cole, C. (2014). Audit Partner Accountability and Audit Transparency: Partner Signature or Disclosure Requirement. Journal of Accounting and Finance, 14(2), 84-101.

Daske, H., Luzi, H., Leuz, C., \& Verdi, R. (2008). Mandatory IFRS reporting around the world: Early evidence on the economic consequences. Journal of Accounting Research, 46(5), 1085-1142. https://doi.org/10.1111/j.1475-679X.2008.00306.x

DeZoort, T., Harrison, P., \& Taylor, M. (2006). Accountability and auditors' materiality judgments: The effects of differential pressure strength on conservatism, variability, and effort. Accounting, Organizations and Society, 31(4/5), 373-390. https://doi.org/10.1016/j.aos.2005.09.001

Diamond, D. (1985). Optimal release of information by firms. The Journal of Finance, 40, 1071-1094. https://doi.org/10.1111/j.1540-6261.1985.tb02364.x

Diamond, D., \& Verrecchia, R. (1991). Disclosure, liquidity and cost of capital. Journal of Finance, 46(4), 1325-1359. https://doi.org/10.1111/j.1540-6261.1991.tb04620.x

Easley, D., \& O'Hara, M. (2004). Information and the cost of capital. The Journal of Financ, 59(4), 1553-1583. https://doi.org/10.1111/j.1540-6261.2004.00672.x

Ernsberger, J., Krotter, S. S., \& Stadler, C. (2008). Analysts' forecast accuracy in Germany: The effect of different accounting principles and changes of accounting principles. Business Research, 1, 26-53. https://doi.org/10.1007/BF03342701

European Parliament and the Council of the European Union. (2006) Directive 2006/43/EC of the European Parliament and of the Council. Available at: http://eur-lex.europa.eu/LexUriServ/LexUriServ.do?uri1/4OJ:L:2006:157:0024:0086:en:PDF

Francis, J. R., Khurana, I. K., \& Pereira, R. (2005). Disclosure incentives and effects on cost of capital around the world. The Accounting Review, 80(4), 1125-1162. https://doi.org/10.2308/accr.2005.80.4.1125

Glosten, L., \& Milgrom, P. (1985). Bid, ask, and transaction prices in a specialist market with heterogeneously informed traders. Journal of Financial Economics, 26, 71-100. https://doi.org/10.1016/0304-405X(85)90044-3

Hagafors, R., \& Brehmer, B. (1983). Does having to justify one's judgments change the nature of the judgment process? Organizational Behavior and Human Decision Processes, 223-232. https://doi.org/10.1016/0030-5073(83)90122-8 
Healy, P., Hutton, A., \& Palepu, K. (1999). Stock performance and intermediation changes surrounding sustained increases in disclosure. Contemporary Accounting Research, 16, 485-520. https://doi.org/10.1111/j.1911-3846.1999.tb00592.x

Hodgdon, C., Tondkar, R., Harless, D., \& Adhikari, A. (2008). Compliance with IFRS disclosure requirements and individual analysts' forecast errors. Journal of International Accounting, Auditing, and Taxation, 17, 1-13. https://doi.org/10.1016/j.intaccaudtax.2008.01.002

Horton, J., Serafeim, G., \& Serafeim, I. (2013). Does mandatory IFRS adoption improve the information environment? Contemporary Accounting Research, 30, 388-423. https://doi.org/10.1111/j.1911-3846.2012.01159.x

John, K., Liu, M., \& Sunder, J. (2017). Do client firms benefit from mandatory engagement partner signature? Working Paper. Temple University.

Johnson, V. E., \& Kaplan, S. E. (1991). Experimental evidence on the effects of accountability on auditor judgments. Auditing: A Journal of Practice \& Theory, 10(Supplement), 96-107.

Jones, J. (1991). Earnings management during import relief investigations. Journal of Accounting Research, 29, 193-228. https://doi.org/10.2307/2491047

Kalay, Z. (2012). Reaction kinetics in the plasma membrane. Biotechnology Journal, 7(6), 745-752. https://doi.org/10.1002/biot.201100362

Kennedy, J. (1993). Debiasing audit judgment with accountability: A framework and experimental results. Journal of Accounting Research ,31(2), 231-245. https://doi.org/10.2307/2491272

Knechel, W. R., Vanstraelen, A., \& Zern, M. (2015). Does the Identity of Engagement Partners Matter? An Analysis of Audit Partner Reporting Decisions. Contemporary Accounting Research, 32(4), 1443-1478. https://doi.org/10.1111/1911-3846.12113

Kothari, S. P., Leone, A. J., \& Wasley, C. E. (2005). Performance matched discretionary accrual measures. Journal of Accounting and Economics, 39(1), 163-197. https://doi.org/10.1016/j.jacceco.2004.11.002

Lambert, R., Leuz, C., \& Verrecchia, R. E. (2007). Accounting information, disclosure, and the cost of capital. Journal of Accounting Research, 45(2), 385-420. https://doi.org/10.1111/j.1475-679X.2007.00238.x

Lambert, R., Leuz, C., \& Verrecchia, R. E. (2011). Information asymmetry, Information precision, and the cost of capital. Review of Finance, 16(1), 1-29. https://doi.org/10.1093/rof/rfr014

Lang, M., \& Lundholm, R. (1993). Cross-sectional determinants of analyst ratings of corporate disclosures. Journal of Accounting Research, 31, 246-271. https://doi.org/10.2307/2491273

Lang, M., \& Lundholm, R. (1996). Corporate disclosure policy and analyst behavior. The Accounting Review, 71, 467-492

Lehavy, R., Li, F., \& Merkley, K. (2011). The Effect of Annual Report Readability on Analyst Following and the Properties of Their Earnings Forecasts. The Accounting Review, 86(3), 1087-1115. https://doi.org/10.2308/accr.00000043

Lennox, C. S., Wu, X., \& Zhang, T. (2014). Does mandatory rotation of audit partners improve audit quality? The Accounting Review, 89, 1775-1803. https://doi.org/10.2308/accr-50800

Leuz, C., \& Verrecchia, R. (2000). The economic consequences of increased disclosure. Journal of Accounting Research, 38, 91-124. https://doi.org/10.2307/2672910

Liu, S. (2017). Does the requirement of an engagement partner signature improve financial analysts' information environment in the United Kingdom? Review of Quantitative Finance and Accounting, 49, 263-281. https://doi.org/10.1007/s11156-016-0590-0

Lobo, G., Song, M., \& Stanford, M. (2012). Accruals quality and analyst coverage. Journal of Banking \& Finance, 36, 497-508. https://doi.org/10.1016/j.jbankfin.2011.08.006

Mcallister, D. W., Mitchell, T. R., \& Beach, L. R. (1979). The contingency model for the selection of decision strategies: An empirical test of the effects of significance, accountability, and reversibility. Organizational Behavior and Human Decision Processes, 228-244. https://doi.org/10.1016/0030-5073(79)90027-8

O’Brien, P., \& Bhushan, R. (1990). Analyst following and institutional ownership. Journal of Accounting Research, 28, 55-76. https://doi.org/10.2307/2491247 
Petersen, M. (2009). Estimating standard errors in finance panel data sets: Comparing approaches. The Review of Financial Studies, 22, 435-480. https://doi.org/10.1093/rfs/hhn053

Pricewaterhousecoopers (PWC) Legal. (2010) A practical guide to the companies act of 2006-Aguide for busy directors and company secretaries. UK: $\mathrm{CCH}$.

Public Company Accounting Oversight Board (PCAOB). (2009). Requiring the Engagement Partner to Sign the Audit Report. Concept Release No. 2009-005. Available at: http://pcaobus.org/Rules/Rulemaking/Docket029/2009-07-28_Release_No_2009-005.pdf

Public Company Accounting Oversight Board (PCAOB). (2011). Improving the Transparency of Audits: Proposed Amendments to PCAOB Auditing Standards and Form 2. Concept Release No. 2011-007. Available at: http://pcaobus.org/Rules/Rulemaking/Docket029/PCAOB_Release_2011-007.pdf

Public Company Accounting Oversight Board (PCAOB). (2013). Improving the transparency of audits: Proposed amendments to PCAOB auditing standards to provide disclosure in the auditor's report of certain participants in the audit. Release No. 2013-009. Available at:

http://pcaobus.org/Rules/Rulemaking/Docket029/PCAOB\%20Release\%20No\%20\%202013-009\%20-\%20T ransparency.pdf

Public Company Accounting Oversight Board (PCAOB). (2015). Improving the transparency of audits: Rules to require disclosure of certain audit participants on a new $\mathrm{PCAOB}$ form and related amendments to auditing standards. PCAOB Release No. 2015-008 December 15, 2015. Available at: https://pcaobus.org/Rulemaking/Docket029/Release-2015-008.pdf

Tan, H., Wang, S., \& Welker, M. (2011). Analyst following and forecast accuracy after mandated IFRS adoption. Journal of Accounting Research, 49, 1307-1357. https://doi.org/10.1111/j.1475-679X.2011.00422.x

Tetlock, P. E., Skitka, L., \& Boettger, R. (1989). Accountability: A social magnifier of the dilution effect. Journal of Personality and Social Psychology, 388-398. https://doi.org/10.1037/0022-3514.57.3.388

US Department of the Treasury. (2008). Final report of the advisory committee on the auditing profession (ACAP). Government Printing Office, Washington, DC

Welker, M. (1995). Disclosure policy, information asymmetry, and liquidity in equity markets. Contemporary Accounting Research, 11, 801-827. https://doi.org/10.1111/j.1911-3846.1995.tb00467.x

\section{Copyrights}

Copyright for this article is retained by the author(s), with first publication rights granted to the journal.

This is an open-access article distributed under the terms and conditions of the Creative Commons Attribution license (http://creativecommons.org/licenses/by/4.0/). 